\title{
The importance of context in managerial work: the case of senior hotel managers in Greece
}

\author{
Charalampos Giousmpasoglou \\ Business School, Bahrain Polytechnic, Kingdom of Bahrain
}

\begin{abstract}
Qualitative research on the interplay between context and hospitality managerial work has not been previously addressed in literature. Based on Johns (2006) and Dierdorff et al. (2009) work, this research suggests that luxury senior hotel managers (GMs and department managers) are recipients of contextual/cultural influences to a certain degree, depending on the ownership status of the hotel. It is also argued that managerial work is shaped and exercised by a set of moderating factors, which are unique for each individual. Overall, this research aims to increase the level of awareness and trigger further research in this topic area.
\end{abstract}

Key Words Managerial work, Context, Luxury hotels, Greece

Paper Type Research Paper

\section{INTRODUCTION}

For the past half-century, management scholars and practitioners have engaged in research to describe managerial work. This body of research has focused on making management an absolute science, making important strides in creating a body of 'standard' (common) management practices. Along the way they created generations of managers who believed that managerial work could be described in absolute terms, even quantified, and that predictions about some future business events could be devised (i.e. through scenario planning and modeling, or trend analysis). In short, too many managers gave the science of management more credit for being mature than the field deserved, based on extensive use of data and information, and not necessarily on more tacit inputs, such as context.

Address correspondence to Dr. Charalampos Giousmpasoglou, Business School, Bahrain Polytechnic, PO Box 33349, Isa Town, Kingdom of Bahrain, E-mail: c.giousmpasoglou@polytechnic.bh; babisyious@gmail.com 
Although organisational studies provide evidence that context matters to managerial work, theoretical efforts describing the relationships between context and managerial work have remained absent. The way in which work context shapes the requirements of managerial role enactment is a vital issue in its own right, because the extent to which individuals view various activities and attributes as important to enacting their work roles is central to how they ultimately perform those roles (Dierdorff \& Rubin, 2007). Given the paucity of literature in this area, the purpose of this paper is to explore the interplay of context with managerial work in the Greek luxury hotel sector. In order to achieve this, there are three objectives:

- To identify the key managerial roles performed by senior managers (GMs and department managers) in the Greek luxury hotel sector.

- To explore the level of influence of the local/national context to managerial work.

- To develop a model of the process through which definitions and perceptions of the required management roles in different contexts are formed.

\section{LITERATURE REVIEW}

\section{Managerial Work in Context}

Theoretical and empirical efforts focusing on the interplay between work context and managerial roles have been conspicuously absent despite the recognition that context meaningfully shapes organisational behaviour (Dierdorff et al., 2009). Work context can be thought of as a set of moderating factors that influence the employee's behaviour and adaptation (Strong et al., 1999). Dierdorff et al. (2009) suggest that there have been two exceptions to this general tendency. The first exception refers to scholars who have studied managers at work, by interviewing or observing them as they go about their day-to-day activities (Carlson, 1951; Kotter, 1982; Luthans et al., 1985; Mintzberg, 1973, 1994; Sayles, 1964; Silverman \& Jones, 1976; Stewart, 1982). The second exception refers to scholars who have been interested in how organisational factors can influence managerial behaviour from a cognitive perspective (Hammer \& Turk, 1987; Osborn \& Hunt, 1975). Stewart (1982) showed that all managerial jobs offer choice and that managers perceive similar jobs in personal ways. Other studies using a cognitive approach are Hannaway (1989) and Watson (2001). 
Another crucial aspect that is largely neglected in managerial work research is premised in the fact that, the structure of work in organisations is partially a social construction (Sanchez \& Levine, 2000; Weick, 1979). Thus, the job performed by organisational members reflects specific activities performed within the job as well as the capabilities, preferences, and opinions of the role holders (Morgeson \& Campion, 1997). Because of this, similar roles are often enacted in different ways (Biddle, 1979; Graen, 1976; Katz \& Kahn, 1978) within different contexts (Dierdorff \& Morgeson, 2007; Johns, 2006). More recently Dierdorff et al. (2009) argued that context can exert a profound influence on what work role requirements are more or less important for managers. Despite this implicit recognition, and the fact that managerial work roles occur in diverse work contexts, there have been very few empirical examinations of how different aspects of work context shape managerial behavior (Dierdorff \& Morgeson, 2007; Mowday \& Sutton, 1993; Schneider, 1983). This gap in managerial work role literature is not necessarily surprising given the general lack of consideration of context in organisational research (Cappelli \& Sherer, 1991; Hattrup \& Jackson, 1996; Johns, 2006).

\section{Placing Managerial Work in Context}

Knowing how to understand and leverage context remains one of the most basic requirements in work life, yet very difficult to achieve in managerial work (Cortada, 2009). Johns (2006, p.386) defines context as 'situational opportunities and constraints that affect the occurrence and meaning of organisational behaviour as well as functional relationships between variables'. In his review, Johns (ibid.) puts forth a categorical model of context that can be used to inform inquiry about such influences on managerial roles. Specifically, he conceptualised context at two levels. The first level is termed omnibus context and the second discrete context.

According to Johns (2006, p.391) the term omnibus 'refers to an entity that comprises many features or particulars'. The omnibus context provides information about the broad essential elements of a given context and describes managerial roles' moderating influences collectively in a nondifferentiated manner (Johns, 2006). Dierdorff et al. (2009) suggest that the omnibus context is synonymous with occupation when studying work roles; they also argue that occupation accounts for variance in the importance of role requirements across different managerial work roles. Such variances 
in effect linked to omnibus context suggest that managerial requirements that are technical/ administrative are likely to be the most occupation specific, whereas interpersonal and conceptual requirements are more universally important.

On the other hand, discrete context seeks to identify specific situational variables that impact behavior directly or indirectly (Dierdorff et al., 2009). Discrete context can be viewed as nested within omnibus context such that the effects of omnibus context are mediated by discrete contextual variables; these variables might apply to any level of analysis, from individuals to industries (Johns, 2006). Three important components compose the discrete context and shape role requirements: task context, social context, and physical context (Hattrup \& Jackson, 1996, Johns, 2006; Mowday \& Sutton, 1993).

A type of discrete context discussed by Johns (2006) is the discrete occupational context. Discrete occupational contexts arise from the nature of the work itself, such that 'knowing someone's occupation permits reasonable inferences about his or her task, social, and physical environment at work, which, in turn, can be used to predict behaviour and attitudes' (Johns, 2006, p.393). Building on managerial work role literature and Johns' (2006) categorical model of work context, Dierdorff et al. (2009) developed an integrative meso-level framework (House et al., 1995) that links features of the work context (omnibus context) to individual role enactment (discrete context). The importance of the identification of a mesotype relationship between the omnibus and the discrete contexts lies in the fact that allows us to make limited generalizations about specific categories of occupational groups; in other words allows us to create different managerial profiles in the same job. The existence of discrete occupational contexts allows us the creation of generic descriptions in occupational contexts i.e. luxury hotel managers. Thus, the research conducted was an effort to map managerial work in luxury hotels in Greece, based on the existing occupational context.

\section{Managerial Work in Hotels}

The profile of the modern hotel GM, has been largely affected from the multinational (MNC) hotel chains, operating worldwide. The early adoption of internationalisation in the hotel industry came initially from U.S. hotel companies, who took the lead and moved across borders for supply and 
demand reasons; that was to satisfy the needs of American travellers as other trades internationalised (Nickson, 1998; Thompson et al., 1998). Since the early 1980s a growing number of these original American operators were acquired by U.K. based companies, and simultaneously other European and Asian companies began to compete on more broadly international scales (Segal-Horn, 1994; Thompson et al., 1998). The transformation of the sector in a truly globalised industry occurred after a prolonged period of mergers and acquisitions during the 1990s. This brought changes in the adopted growth strategies of many hotel companies who were now competing on a global basis (Price, 1993). While the hotel industry was traditionally dominated by individually and/or family owned properties it can be argued that it is heavily influenced by international/multinational hotel companies (Litteljohn, 2003). In this globalised environment, the development of international hospitality managers is seen as being of critical importance for hospitality MNCs. Thus, since the early 1990s, the rapid growth of international hotel chains and its effects on managerial work, have drawn the attention of researchers (i.e. Adler \& Rigg, 2012; Gilbert \& Guerrier, 1997; Ladkin \& Juwaheer, 2000; Miao et al., 2011; Nebel et al., 1995). The personality characteristics required of the international hotel managers include people and interpersonal skills, adaptability, flexibility and tolerance, cultural sensitivity and intercultural competence followed by emotional maturity, industry experience, and self-confidence (Feng \& Pearson, 1999; Kriegl, 2000; Shay \& Tracey, 1997). International etiquette, demonstrating an understanding of international business matters, the ability to work with limited resources and effectively manage stress were judged to be relatively important, while functional and technical skills were rated as the lowest priority for managers. Research also indicates that in an international hospitality organisation building managers' cross cultural skills may be far harder but more important than developing their functional and technical skills (Kriegl, 2000; Shay \& Tracey, 1997).

Despite the economic significance and global spread of the international hospitality industry, the majority of hospitality management literature reflects what has happened in the US and the UK since the early 1980s. The ignorance of hospitality managerial work in different contexts has created a gap in the extant literature. Dierdorff's et al. (2009) categorical model of work context, certainly adds value to the argument that in order to understand managerial work in hotels, researchers need to think and work outside the Anglo-American context. Boyacigiller and Alder (1991) argue that this bias in 
theory development is the result not of an inherent belief in the superiority of U.S. management but of parochialism - a lack of awareness of alternative contexts, models, research and values. As a result the cultural context is often ignored in management research and universality is assumed (Thomas, 2008). Recently, a number of scholars have challenged the assumption that management theories formulated in one country are applicable universally, and have demonstrated in their research that management theories applicable in one country cannot be generalised directly to other countries (i.e. House et al., 2004; Javidan et al., 2005). In addition, only recently have studies focused on what is happening in the rest of the Europe or the world (i.e. Agut et al., 2003; Blayney, 2009; Christou \& Eaton, 2000; Jauhari, 2006). This was made possible through the contribution of a steadily growing number of overseas students in the U.S. and U.K. business schools who deliver hospitality programs. The most popular forms of research used to study the hospitality industry outside the Anglo-American context, is the use of country case studies (i.e. Agut et al, 2003; Christou, 1999; Kim, 1994) and studies within the context of the international hospitality business (D'Annunzio-Green, 1997). Despite the relatively slow progress, hospitality research persistently reflects the Anglo-American universalist approach to management.

\section{Managerial roles in hotels}

The roles that managers play in performing their jobs and the relationship of managerial roles to managerial effectiveness and performance are the foci of considerable research interest in hospitality. During the 1990s, there have been further studies of managerial work in the hospitality industry, notably by Nebel and Ghei (1993) and Hales and Tamangani (1996). Two interrelated themes recur through this work, as well as in the earlier studies (Guerrier \& Deery, 1998). Firstly, to what extent is the work of hospitality managers influenced by the industry context? Secondly, to what extent do hospitality managers engage in reaction or reflection? Is their role essentially about coping with the immediate, operational problems, or to what extent do and should they act as strategic thinkers? In an effort to answer the above questions, Nebel and Ghei (1993) developed a conceptual framework of the GM's work roles in hotels. They suggested that a hotel GM's job can be better understood by examining the contextual variables that influence and help shape it. In addition they argued that a 
hotel's context presents GMs with a series of job demands and relationship issues with which they must deal effectively in order to be able to perform successfully. These contextual elements (job demands and relationship issues) differ depending on the time frame (short-run, intermediate-run, or long-run) under consideration. These considerations give rise to specific job functions that GMs perform through a variety of work roles:

- In the short run, the GM job function was described, based on Mintzberg's (1973) model, as that of operational controller.

- In the intermediate run (medium term), the GM job function was described as that of organisational developer.

- In the long run, the GM's job function was described as that of business maintainer.

Hales and Tamangani (1996) drew similar conclusions in relation to hotel unit GMs. Firstly, most of the day-to-day operational problems in hotels are service centred and therefore a major focus of the role of any hotel manager must be on the management of service quality. They argued that where retail unit managers place an emphasis on reactive customer administration, hotel managers place it on proactive service quality management. Secondly, most of the day-to-day business problems in hotels have extremely short time leads. Whilst managers should also concern themselves with the medium and long term needs (notably the development of staff) 'the pressing needs of the immediate and recurrent often drive out longer-term considerations' (Hales \& Tamangani, 1996, p.748).

\section{APPROACH/METHODOLOGY}

In an effort to understand better the nature of managerial work in different cultural contexts, this paper explores the interaction of all three levels of context with managerial work in luxury hotels. The research methodology of this study, findings and conceptual framework follow below.

As already discussed above, managerial work is shaped and exercised in context, and cannot be viewed in isolation (Dierdorff et al., 2009; Johns, 2006). How and why those hotel managers develop and exercise their roles in a given organisational and national context, formed the main focus of the data to be collected. As such the author was inclined towards the qualitative research preferences 
(Guba \& Lincoln, 1994; Harris, 2008) rather than any specific testing of established hypotheses or conscious counting of objective social events. By attempting to generate an interpretive analysis of the meanings and stories of luxury hotel managers, it was hoped to arrive at theoretical propositions about the way hotel managers exercise their roles. Whilst the interpretivist perspective informed the main choice of research design the author was also keen to complement his study with some insights into the Greek luxury hotel sector; as such the more quantitative aspects (geographical spread, size and structure of the industry) were used to help understand the GMs' work context alongside the more important qualitative aspects (what/why/how in managerial roles).

In total 32 participant senior managers (16 GMs and 16 department managers) from16 hotels were chosen - representing 4 and $5^{*}$ in the country's most popular tourist destinations (Athens, Thessaloniki, Rhodes and Crete). The decision to include apart from GMs also department managers is based in the fact that in Greece, department managers (mainly from the F\&B Department and the Rooms Division) participate in decision making at strategic level. In addition, most of the GMs in luxury hotels in Greece originate from the above mentioned departments (Giousmpasoglou, 2012); thus it is very common to find department managers with acting GM's roles.

The 16 establishments selected for this research, represent two broad hotel types operating in Greece - city and resort. In addition, these hotels have as common denominators the same star rating (4* and $\left.5^{*}\right)$, type (city or resort), size (medium to big hotels, over 150 beds) and ownership status (family; local Greek chain; national Greek Chain; multinational chain). The hotel selection process followed in this research was dictated by the structure of the luxury hotel industry in Greece: given its nature and geographical spread (approximately 1,150 establishments all over Greece) a decision was made to limit the destinations in the most representative and popular places for city and resort hotels respectively.

A two-part tool followed by a cover letter explaining the aim of the interview was used, in order to serve the needs of the research. The first part examined demographic data of the company and the participant manager; the second part was a 14 question semi-structured in-depth interview (Appendix 1). The questions set emerged from the literature review, the purpose and the objectives of this research. Thus, the interview questions examine various aspects of managerial work in hotels such as: 
recruitment and selection; training and development; managerial roles and competencies; performance appraisal; relations with stakeholder (i.e. hotel owners, customers, employees, suppliers); networking; hotel ownership status; cultural/contextual influences. The planning and conduct of the interviews were proven a great challenge: although a protocol was used to approach the GMs (Table 1), it was the author's professional network that actually made this happen. After the managers' positive responses the interviews were organised as part of a 'hotel day visit' and took place in the participants' offices. A consent form (Personal Data Protection Declaration) - prepared by the author - was signed before each interview on behalf the author on the one hand, and the participant manager on the other (Giousmpasoglou, 2012). This involved issues such as disclosure of company information to third party and guaranty of anonymity for the participants and the company. The interviews were voice recorded and then transcribed; the average length of an interview was 45 minutes.

Table 1 Case access methods and arrange time to finalise appointment

\begin{tabular}{|c|c|c|c|c|c|c|}
\hline \multicolumn{2}{|c|}{ Region / Hotel } & E-mail & Telephone & $\begin{array}{c}\text { Networking / } \\
\text { Recomme- } \\
\text { ndations } \\
\end{array}$ & $\begin{array}{c}\text { Snowball } \\
\text { Effect }\end{array}$ & $\begin{array}{c}\text { Time to } \\
\text { finalise } \\
\text { appointment }\end{array}$ \\
\hline \multicolumn{7}{|c|}{ City hotels } \\
\hline 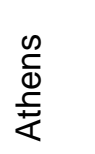 & $\begin{array}{l}\text { Hotel } 1 \\
\text { Hotel } 2 \\
\text { Hotel } 3 \\
\text { Hotel } 4\end{array}$ & $\begin{array}{l}\checkmark \\
\checkmark \\
\checkmark \\
\checkmark\end{array}$ & $\begin{array}{l}\checkmark \\
\checkmark \\
\checkmark \\
\checkmark\end{array}$ & $\begin{array}{l}\checkmark \\
\checkmark \\
\checkmark \\
\checkmark\end{array}$ & $\begin{array}{l}x \\
\checkmark \\
\checkmark \\
\checkmark\end{array}$ & $\begin{array}{l}2 \text { months } \\
1,5 \text { months } \\
3 \text { months } \\
2 \text { months }\end{array}$ \\
\hline 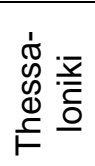 & $\begin{array}{l}\text { Hotel } 5 \\
\text { Hotel } 6 \\
\text { Hotel } 7 \\
\text { Hotel } 8\end{array}$ & $\begin{array}{l}\checkmark \\
\checkmark \\
\checkmark \\
\checkmark\end{array}$ & $\begin{array}{l}\checkmark \\
\checkmark \\
\checkmark \\
\checkmark\end{array}$ & $\begin{array}{l}\checkmark \\
\checkmark \\
\checkmark \\
\checkmark\end{array}$ & $\begin{array}{l}x \\
x \\
\checkmark \\
\checkmark\end{array}$ & $\begin{array}{c}1 \text { month } \\
1,5 \text { months } \\
3 \text { weeks } \\
1 \text { month }\end{array}$ \\
\hline \multicolumn{7}{|c|}{ Resort hotels } \\
\hline $\begin{array}{l}\frac{0}{ \pm} \\
\frac{0}{U}\end{array}$ & $\begin{array}{l}\text { Hotel } 9 \\
\text { Hotel } 10 \\
\text { Hotel } 11 \\
\text { Hotel } 12\end{array}$ & $\begin{array}{l}\checkmark \\
\checkmark \\
\checkmark \\
\checkmark\end{array}$ & $\begin{array}{l}\checkmark \\
\checkmark \\
\checkmark \\
\checkmark\end{array}$ & $\begin{array}{l}x \\
x \\
\checkmark \\
\checkmark\end{array}$ & $\begin{array}{l}x \\
x \\
\checkmark \\
x\end{array}$ & $\begin{array}{l}1 \text { week } \\
3 \text { weeks } \\
1 \text { month } \\
3 \text { weeks }\end{array}$ \\
\hline $\begin{array}{l}0 \\
\frac{0}{8} \\
\frac{0}{x}\end{array}$ & $\begin{array}{l}\text { Hotel } 13 \\
\text { Hotel } 14 \\
\text { Hotel } 15 \\
\text { Hotel } 16\end{array}$ & $\begin{array}{l}\checkmark \\
\checkmark \\
\checkmark \\
\checkmark\end{array}$ & $\begin{array}{l}\checkmark \\
\checkmark \\
\checkmark \\
\checkmark\end{array}$ & $\begin{array}{l}\checkmark \\
\checkmark \\
\checkmark \\
\checkmark\end{array}$ & $\begin{array}{l}\mathbf{x} \\
\mathbf{x} \\
\mathbf{x} \\
\mathbf{x}\end{array}$ & $\begin{array}{l}3 \text { weeks } \\
3 \text { weeks } \\
2 \text { weeks } \\
3 \text { weeks }\end{array}$ \\
\hline
\end{tabular}

A major methodological concern for this study was to produce valid and reliable outcomes. A research protocol was used (Appendix 2) as recommended by Yin (2003). The case study protocol contains procedures and general rules that should be followed in using the research instrument/s and is considered essential in a multiple-case study (Yin, ibid.). It was created prior to the data collection 
phase. In addition, during the data collection tests for the quality of research were employed (Construct and External Validity, Reliability); these tests were followed by the use of two different triangulation methods namely Data and Methodological triangulation. Data triangulation involves the use of a variety of data sources in a study (Denzin \& Lincoln, 2003). Thus, next to primary data from the thirty-two interviews, secondary data were also an important source of information. Multiple types of documents were collected for each case and included the following: applications for employment, company vision / mission statement, promotional material (including audio-visual material like DVDs), company newspapers, performance evaluation forms and any other printed material that could provide information for this study. A second way to triangulate data was to write field notes during and immediately after each interview session. These notes were especially useful as they shed additional light on the textual content or indicated specific questions that do not directly appear in the interview transcripts. In this context it can be argued that recording the meaning of what is being said rather than the exact words of the respondent is more important in this context (Perry, 1998; Stake, 1995). On the other hand Method triangulation entails the use of multiple methods to study a single problem (Decrop, 1999). This can be different qualitative methods or a combination of qualitative and quantitative techniques (but not in hierarchical order like qualitative exploration and quantitative inference). Since each method has its own limits and biases, and single methodologies result in personal biases, using multiple methods paves the way for more credible and dependable information. As already mentioned above, this research employed in-depth, semi-structured interviews measuring the participants' perceptions. Additional information for each case was retrieved from demographics statistical data referring to the luxury hotel managers in Greece.

\section{RESEARCH FINDINGS AND DISCUSSION}

The research findings are presented below in three levels based on Johns (2006) and Dierdorff's et al. (2009) categorical model of work context, discussed above. In order to categorize and analyze the gathered data easier, a participant hotel and manager coding was developed (Table 2). 
Table 2 Participant hotels and managers coding explained

\begin{tabular}{|c|c|c|c|c|c|}
\hline $\begin{array}{l}\text { Hotel } \\
\text { Coding }\end{array}$ & Hotel location & $\begin{array}{l}\text { Ownership } \\
\text { status }\end{array}$ & $\begin{array}{c}\text { Hotel } \\
\text { country } \\
\text { of origin }\end{array}$ & $\begin{array}{c}\text { Participant } \\
\text { manager } 1 \\
\text { position }\end{array}$ & $\begin{array}{c}\text { Participant } \\
\text { manager } 2 \\
\text { position }\end{array}$ \\
\hline H1 & Athens & GR/L/Ch & GR & GM & HR mgr \\
\hline $\mathrm{H} 2$ & Athens & GR/N/Ch & GR & GM & $\mathrm{F} \& \mathrm{~B}$ mgr \\
\hline H3 & Athens & MNC & USA(F) & GM & $\mathrm{F} / \mathrm{O} \mathrm{mgr}$ \\
\hline H4 & Athens & FAMILY & GR & GM & $F \& B$ \\
\hline H5 & Thessaloniki & GR/N/Ch & GR & GM & $F \& B$ \\
\hline $\mathrm{H} 6$ & Thessaloniki & MNC & USA(M) & GM & Ops mgr \\
\hline $\mathrm{H} 7$ & Thessaloniki & GR/N/Ch & GR & GM & $\mathrm{F} / \mathrm{O} \mathrm{mgr}$ \\
\hline H8 & Thessaloniki & FAMILY & GR & GM & $\mathrm{F} / \mathrm{O} \mathrm{mgr}$ \\
\hline H9 & Crete & FAMILY & GR & GM & $\mathrm{F} / \mathrm{O} \mathrm{mgr}$ \\
\hline H10 & Crete & MNC & $\mathrm{CY}(\mathrm{M})$ & GM & Ops mgr \\
\hline H11 & Crete & GR/L/Ch & GR & GM & $\mathrm{F} \& \mathrm{~B}$ mgr \\
\hline $\mathrm{H} 12$ & Crete & GR/L/Ch & GR & GM & F\&B mgr \\
\hline H13 & Rhodes & MNC & USA(M) & Ops mgr & $\mathrm{F} \& \mathrm{~B} \mathrm{mgr}$ \\
\hline H14 & Rhodes & GR/L/Ch & GR & GM & $\mathrm{F} \& \mathrm{~B} \mathrm{mgr}$ \\
\hline H15 & Rhodes & FAMILY & GR & GM & $\mathrm{F} \& \mathrm{~B} \mathrm{mgr}$ \\
\hline H16 & Rhodes & $\mathrm{GR} / \mathrm{N} / \mathrm{Ch}$ & GR & GM & $\mathrm{F} / \mathrm{O} \mathrm{mgr}$ \\
\hline \multicolumn{3}{|c|}{$\begin{array}{ll}\text { Family: } & \text { Greek family owned hotel } \\
\text { GR/L/Ch: } & \text { Greek local chain hotel } \\
\text { GR/N/Ch: Greek national chain hotel } \\
\text { MNC: } \quad \text { Multinational hotel chain } \\
& \text { operating in Greece } \\
\text { M: Managed / F: Franchised }\end{array}$} & $\begin{array}{l}\text { Manageria } \\
\text { GM: } \\
\text { Ops Mgr: } \\
\text { F\&B Mgr: } \\
\text { F/O Mgr: } \\
\text { HR Mgr: }\end{array}$ & \multicolumn{2}{|c|}{$\begin{array}{l}\text { Hotel unit general manager } \\
\text { Operations manager } \\
\text { Food \& beverage manager } \\
\text { Front office manager } \\
\text { Human resources manager }\end{array}$} \\
\hline
\end{tabular}

\section{Level 1: The Generic Context of Managerial Work}

The starting point of this research is the omnibus context that provides the generic descriptions of managerial work in hospitality. Evidence from this research suggests that the complex nature of hotel GMs, is discerned where the respondents highlight the importance in developing and managing culturally diverse relationships with a range of stakeholders (i.e. ownership, subordinates, customers and local authorities) under atypical and sometimes hostile environmental conditions. A franchised multinational hotel GM in Athens (H3) notes that: 
“...it is definitely not my job to be the person to hear staff's or customers' complaints but for God's sake I should be the first person to know... when something wrong happens we should be able to respond immediately as a team...the fire-fighter role is something inevitable when you deal with people and services."

These findings align with a body of literature which identify GMs as valuable resources both to international and local companies, through their crucial representative roles, relationships with owners, investors, local and international businesses, alongside their capacity to generate revenue (Field, 1995; Gilatis \& Guerrier, 1994; Guilding, 2006; Jauncey, 2000; Nebel \& Vidakovic, 1995). The long, intense, experiential, highly mobile and separate nature of GMs' occupational tenure renders it difficult to find alternative sources of expertise. Simultaneously then GMs are deemed to be rare resources, by virtue of the complex combinations of their proprietary knowledge, skills and experiences, while the characteristics and qualities demanded of them are broadly similar across the hospitality, tourism and leisure sector sample, with the strong occupational community amongst hotel managers further enhancing their value (Guerrier, 1987; Jauncey, 2000). The multi-tasking nature of the job was best described in the following words of a local chain GM in Rhodes (H14), who suggests that "due to the limited availability of resources, GMs need to be creative and resourceful, to cope with the everyday challenges and often think 'outside of the box' in order to provide credible solutions". In addition another GM argues:

"It is really very hard to distinguish between formal and informal roles in this hotel... one moment you are in a meeting with the financial manager of the company and the next moment you find yourself arrested in the local police station for a construction permit which has not been issued!... what can I say I love my job but sometimes it is hard to cope with all these challenges at the same time." (Cretan local chain GM - H11)

Overall the research findings suggest that hotel GMs operate in multiple and different contexts. The term used to describe this complex environment is 'Polycontextualisation' (Von Glinow et al., 2005). The effective polycontextualisation of managerial work requires GMs to be armed with knowledge, skills, and capabilities to do so. This research also found that organisational and cultural context respectively, may have a very large impact on the nature of the GMs' work and it is likely that jobs vary as a function of the organisations within which they reside. The following part describes the different types of GMs identified, based on their response to context.

\section{Level 2: The Mesotype Relationship Effect on Managerial Work}

Based on the organisational structure and culture, the findings of this research suggest a clear demarcation between GMs employed in 'local' and 'international' (MNC) business. The identification of three different hotel GM profiles based on the mesotype relationship suggested by Dierdorff et al. 
(2009) was found to be shaped and influenced by certain contextual factors, namely: education attainments; satisfying customer needs and quality; recruitment and selection; training and development; and performance appraisals. These areas emerged from the differentiated approach in managerial work, followed by different hotel types based on the ownership status (family owned; local chain; national chain; multinational chain). Three types of hotel GMs emerged based on the hotel ownership status analysis: the 'native' GMs; the 'Glocal' GMs; and the 'Greek Global' GMs.

'Native' GMs employed in local family businesses acknowledge the value of building social intimacy and maintaining strong personal relationships higher than following standard operating procedures. A Cretan local chain GM (H11) argues that 'you can't ignore the distinctive characteristics of our culture for example the value of filotimo and in-group collectivism that need special handling or approach... the multinational companies cannot understand this dimension for their Greek managers and staff'. In addition, most of the respondents acknowledged the problems created by the Greek context and did not hesitate to air openly their opinions. For example according to a Cretan local chain GM (H11):

"The Greek context definitely influences GMs' work a lot (emphasis)... there is 'a parallel universe' with hidden agendas like bribes, favouritism and nepotism... unfortunately these phenomena are deeply rooted in the Greek society and it would be extremely difficult to extinct".

On the other hand 'Greek Global' GMs employed in MNCs express their trust to corporate standard procedures among the different units operating globally. While local GMs refer to subordinates as colleagues, MNC GMs see people as resources that need to be managed and any local contextual issues are dismissed as irrelevant to their corporate culture. MNC hotel chains GMs work very hard in order to build and maintain a good image as a company, in local communities:

"Understanding and 'manipulating' the (internal and external) environment of the hotel unit is integral part of our job...it is very important for example to know personally the mayor and all the key people in local authorities... they might be useful one day (laughs)". (multinational chain GM in Thessaloniki - H6)

A third approach adopted by the 'Glocal' GMs employed in nationwide operating hotel chains, appreciate both standardisation and the building of social intimacy with key people (i.e. owner, immediate subordinates, repeating clientele, local authorities) inside and outside the various unit. All managers from Greek national hotel chains expressed their appreciation for the value of communication and good relations with staff and customers. The existence of corporate policies and standard operating procedures that require a high level of formality can be considered as the main obstacle in communication. Nevertheless during the interviews, both GMs and department managers argued that they were flexible enough to manoeuvre between formality and informality. According to a national chain F/O manager in Rhodes (H16) 'there's a very delicate balance between people and numbers... you have to be able to understand both if you want to survive in this extremely competitive environment'. Furthermore, it can be argued that those managers are focused in results-oriented roles 
like achieving agreed targets; 'selling' the hotel; materialise budgets; maintain or increase product and service quality standards. According to a Rhodian national chain GM (H16):

"Our roles focus on increasing business for the hotel [this includes selling events and securing contracts with tour operators], monitoring closely the agreed targets for budgets, and co-ordinating efforts for maintaining high standards of quality".

Table 3 The GMs' profile in 4 and 5* hotels in Greece

\begin{tabular}{|c|c|c|c|}
\hline $\begin{array}{c}\text { Manager \& } \\
\text { Company Type }\end{array}$ & \multirow[t]{2}{*}{$\begin{array}{c}\text { The 'Native' GM } \\
\text { (Family /Local Chain) }\end{array}$} & \multirow{2}{*}{$\begin{array}{l}\text { The 'Glocal' GM } \\
\text { (GR Nat. Chain \& } \\
\text { MNC franchised) }\end{array}$} & \multirow{2}{*}{$\begin{array}{c}\text { The 'Greek Global' } \\
\text { GM } \\
\text { (MNC managed) }\end{array}$} \\
\hline $\begin{array}{c}\text { GMs' } \\
\text { characteristics }\end{array}$ & & & \\
\hline Average Age & $55-65$ & $45-55$ & $45-55$ \\
\hline Sex & Male & Male & Male \\
\hline Education & HE Graduates & $\begin{array}{l}\text { HE Graduates \& } \\
\text { Postgraduate Edu. }\end{array}$ & $\begin{array}{l}\text { HE Graduates \& } \\
\text { Postgraduate Edu. }\end{array}$ \\
\hline $\begin{array}{l}\text { Professional } \\
\text { Background }\end{array}$ & $\begin{array}{l}\text { All Departments } \\
\text { (Emphasis in F\&B) }\end{array}$ & $\begin{array}{l}\text { All Departments } \\
\text { (Emphasis in Finance, } \\
\text { Sales \& Contracting) }\end{array}$ & $\begin{array}{c}\text { All Departments } \\
\text { (Emphasis in Finance, } \\
\text { Sales \& Contracting) }\end{array}$ \\
\hline $\begin{array}{l}\text { Recruitment \& } \\
\text { Selection }\end{array}$ & Recommendations & $\begin{array}{l}\text { Head Hunters } \\
\& \text { Internally }\end{array}$ & $\begin{array}{l}\text { Head Hunters } \\
\& \text { Internally }\end{array}$ \\
\hline $\begin{array}{l}\text { Training \& } \\
\text { Development }\end{array}$ & $\begin{array}{c}\text { Sporadic-GMs' own } \\
\text { discretion }\end{array}$ & $\begin{array}{l}\text { Moderate to High } \\
\text { Opportunities }\end{array}$ & High Opportunities \\
\hline Job Roles & "Figurehead" & Leader \& Entrepreneur & Leader \& Entrepreneur \\
\hline Competencies & $\begin{array}{c}\text { Emphasis in } \\
\text { Communication }\end{array}$ & Leadership & $\begin{array}{l}\text { Results Orientation } \\
\text { \& Leadership }\end{array}$ \\
\hline $\begin{array}{l}\text { Performance } \\
\text { Evaluation }\end{array}$ & Informal Annual & $\begin{array}{l}\text { Formal Annual } \\
\text { ( } 1 \text { or } 2 \text { times) }\end{array}$ & $\begin{array}{l}\text { Formal Annual } \\
\text { ( } 1 \text { or } 2 \text { times) }\end{array}$ \\
\hline $\begin{array}{l}\text { Role of } \\
\text { Networking }\end{array}$ & High & $\begin{array}{l}\text { Moderate outside } \\
\text { High inside }\end{array}$ & $\begin{array}{l}\text { Low outside } \\
\text { High inside }\end{array}$ \\
\hline Role of reputation & $\begin{array}{c}\text { High in local /national } \\
\text { market }\end{array}$ & High in national marker & $\begin{array}{l}\text { High in regional / } \\
\text { international market }\end{array}$ \\
\hline $\begin{array}{l}\text { Ownership level of } \\
\text { involvement }\end{array}$ & High to Moderate & Moderate to Low & Low \\
\hline Role of Culture & High & Moderate & Moderate to low \\
\hline
\end{tabular}

In this research, there was no argument on behalf the participant managers that standardisation and local responsiveness have raised conflicting demands; it was however agreed that GMs must incorporate apart from multiple, qualitatively different, embedded cultural contexts. The greatest 
difference with the previous two types of managers (those in family and MNC hotel chains) was that they connected the importance of good staff relations and communication with performance. During the hotel visits, all GMs were found spending most of their times in their office, leaving their immediate subordinates to deal with staff. An Athenian GM in a Greek national chain (H2) said:

"The first thing I do before I get to my office is walk around the hotel to check the condition of the premises and say good morning to as much staff I can...I try to spend some time with them often using small talk to hear if everything's OK with their family... we need to show them that the company cares and the hotel is their second home... on the other hand of course there is distance between me and them, for job matters they have to meet their immediate supervisor".

In summary, it can be argued that although the 'native' GMs acknowledged the western managerial practices, they follow a 'best fit' approach to the management of the hotel and its human resources. On the other hand the 'Glocal' and the 'Greek global' GMs in franchised multinational companies (MNCs), stand successfully between the highly formalised MNC environment and the informal Greek family business environment. Their management style relies on the utilisation of all available human resources, based on a humanistic approach. Finally, the 'Greek global' GMs employed in managed MNC hotel chains, were bound by best practices and corporate policies imposed by the corporate head offices. An overview of the three different GM profiles emerged from the mesotype relationship can be viewed in Table 3 above.

\section{Level 3: The Moderating Effect of Discrete Context on Managerial Work}

One of the key findings of this research is the argument that even within the same job, GMs have different beliefs regarding what their role is about. Role theory has long recognised that individuals holding the same job will perform a slightly different set of tasks, thereby enacting their roles in slightly different ways (Graen, 1976; Katz \& Kahn, 1978; Biddle, 1979; Ilgen \& Hollenbeck, 1991). This research also argues that the way GMs define and perceive their roles, or their role orientation, is a powerful influence on their behaviour, resulting in more or less effective job performance.

In total five themes emerged as factors that influence the shape and development of the GMs' work in luxury hotels in Greece. To start with management mobility, GMs are expected to follow certain career paths that eventually lead to the position of the hotel unit's GM. This research showed limited career path options in Greek hotels with the F\&B and the Front Office departments to appear as the 
only options for career progression. In addition, there was a strong belief that the context is responsible for blocking the Greek hotel managers' careers and potentials:

"There is a sense that Greece has a significant pool of managers that cannot be used properly... this happens for a number of reasons such as bad [hospitality] education, unwillingness of employers to offer more, personal responsibility of the managers themselves, etc".

(Rhodian national chain F/O mgr - H16)

The situation in MNCs and more recently in national hotel chains is different, with career paths being available from finance, sales and marketing. Training and development is seen as an integral part of the HR function within the hotel and is closely related with performance. The HRM departments allocate annual training budgets; they also include succession planning and career development programmes for the middle and senior management. Training can be delivered in-house by existing staff, can be outsourced and delivered by hospitality specialists, or a combination of those two. A national chain GM in Thessaloniki (H5) says:

'...our company allocated this year 80,000€ for senior management training programmes... some of these are developed and delivered in-house, most of them however are outsourced from renown companies in this field...we customise these programmes according to our training needs...this year in a pilot scheme we have send a small group of GMs to Cornell (USA) for short courses in marketing and sales techniques'.

To continue with contact intensity, it poses as the most important theme that influences the managerial roles and competencies in luxury hotels in Greece. GMs communicate daily with a broad spectrum of 'stakeholders' (owners, ownership representatives, subordinates, staff, customers, local authorities officers/public servants); the contact intensity with each stakeholder category determines to a certain degree the managerial roles and competencies adopted. Thus for instance, in family hotels the high level of contact intensity with all stakeholders is deemed important for the survival of the hotel manager, whereas this is not the case for MNC hotel GMs. According to an Athenian family hotel F\&B mgr (H4) a good luxury hotel GM 'must be able to understand, empathise and solve - if possible - people's (meaning staff) problems... satisfied staff equals satisfied customers (emphasis)'. In addition, a national chain F/O manager in Rhodes (H16) argues that 'there's a very delicate balance between people and numbers...you have to be able to understand both if you want to survive in this extremely competitive environment'.

Hierarchy demarcation is the following emerging theme with two contrasting situations emerging from this research. Family and local chain hotel GMs experience difficulties in identifying the limits of their status and authority; the frequent owner interventions and the appointment of family members or friends as members of staff coupled with high levels of informality, influence to a large extent managerial work in Greek hotels and result very often to political behaviour. An Athenian multinational chain F/O mgr (H3) argues that 'owners intervene in the (family) hotel's operations and GM's work... in Greece owners do not have hospitality education... they do not even have an 
elementary business plan in their head'. In other cases the GM's ability to take important decisions is eliminated after interventions that originate from the owner himself or his/her family:

"...they [the owner and his son-GM] often disagree on the way they should run the hotel... in this case you just sit in the corner and listen (emphasis)" "

(Athenian family hotel F\&B mgr - H4)

On the other hand hierarchical demarcation in Greek and MNC hotel chains is strictly orientated and communicated throughout the organisation. The relations between managers and staff reported to be formal and strictly oriented:

"As a senior manager I have to be able to communicate with anyone working in this hotel regardless his/her position... nevertheless hierarchy should be kept at all levels without any distinctions... this is the only way to get the job done without unpleasant surprises"

(Rhodian multinational chain F\&B mgr - H13)

There are however 'unseen' relationships between the hotel unit GMs, superiors and immediate subordinates that determine managerial work to a certain degree. Managers who work in MNC chains do not actually see the owner or even his/her representatives; what they actually do is report directly to the regional or head office in senior corporate executives. A Rhodian multinational chain operations manager (H13) argued that 'a lot of diplomacy is involved in this process...it is not enough to be good, you also need allies to support you in the head or regional office... unfortunately it is not easy to identify friends from foes... you have to be a strong character in order to survive this game'.

Another theme emerging from the Greek context is the manager's integrity in relation to the high levels of corruption in Greece. Although this was considered a sensitive issue, all hotel managers acknowledged the existing problems; in the case of family and local chain hotels GMs contact intensity with public servants and local authorities was reported to be high, so managers are responsible to 'find their own ways' to deal with bureaucracy and corruption. According to a Rhodian family hotel F\&B mgr (H15) “it doesn't matter if you obey the law... at the end of the day you'll have to bribe somebody to take care of your case!" On the other hand national and MNC hotel chain GMs reported that although they have personally no transactions with the public sector, they have contacts to ask for help, 'just in case for a potential difficult, hard to resolve situation' (Athenian Greek national chain $\mathrm{GM}-\mathrm{H} 2$ ).

Finally the hotel GMs' reputation and networking was valued very high from the vast majority of participant managers. There were however variations in the way each type of hotel manager 
participates in networks and builds up his/her own reputation. Thus, managers in family and local chain hotels work very hard to build a good reputation in local, regional or national market; the key in this effort is the participation in the 'right' networks. An Athenian local chain GM (H1) argues that ' $a$ GM's name is very important... it creates prestige for the hotel... helps also the hotel's reputation and enhances the brand name especially in family business...makes it easier for the company to do business'. On the other hand national and MNC chains encourage the participation in managerial networks within the company limits; nevertheless managers in national chains were found to maintain a large number of contacts outside the company limits. Reputation in hotel chains is not valued high, since GMs are appointed based on performance and qualifications. A Rhodian multinational chain F\&B mgr (H13) argues the following regarding networking and reputation:

"The quality of networking in Greece is in lower level than abroad... in multinational hotel chains there is a different mode, everything happens within the limits of the company... only the GM who acts as a corporate representative has the right to develop networks outside the hotel... it is true that you can achieve many things in Greece with networking the matter is how (emphasis)"

In summary, the five emerging themes from this research are responsible for shaping the managers' individual work context, since they set the scene for the development, adoption and exercise of different roles and competencies from each manager in a unique manner.

\section{CONCLUSIONS AND IMPLICATIONS}

This research is an attempt to increase the current body of knowledge of the existing literature on managerial roles in a hospitality, tourism and leisure context. In addition, it can be argued that there are also wider implications for senior managers in a service context. Nevertheless the fact that service environments are very diverse (Grönroos, 2001; Parasuraman et al., 1985), limits the discussion of this research in a hospitality, tourism and leisure context. The assumptions guiding the choice of methods for the research are firmly placed within an interpretive perspective that is committed to a social constructivist philosophy (Burrell \& Morgan, 1979). As such, this research makes a methodological contribution through the use of an interpretive framework, to analyse the perceptions of 36 luxury hotel GMs and department managers in Greece, in relation to managerial work.

The approach taken in this study is positioned within an emergent body of research in the field of managerial work (Dierdorff \& Morgenson, 2007; Dierdorff et al., 2009; Johns, 2006), that applies an 
interpretive paradigm to uncover the complex facets of the managerial work interaction with context. Dierdorff's et al. (2009) categorical model of work context discussed earlier in this paper provided a strong indication of the interaction between context and managerial work in three levels (generic, middle level, specific). The local, national and organisational contexts meet with the GMs personal characteristics and create a unique, 'context specific' situation. This means that managerial work in hotels may demonstrate similarities that allow us to create occupational groupings, but each case is never the same; this is determined by the existing contextual influences in effect, blended with the senior managers' profile (Figure 1)

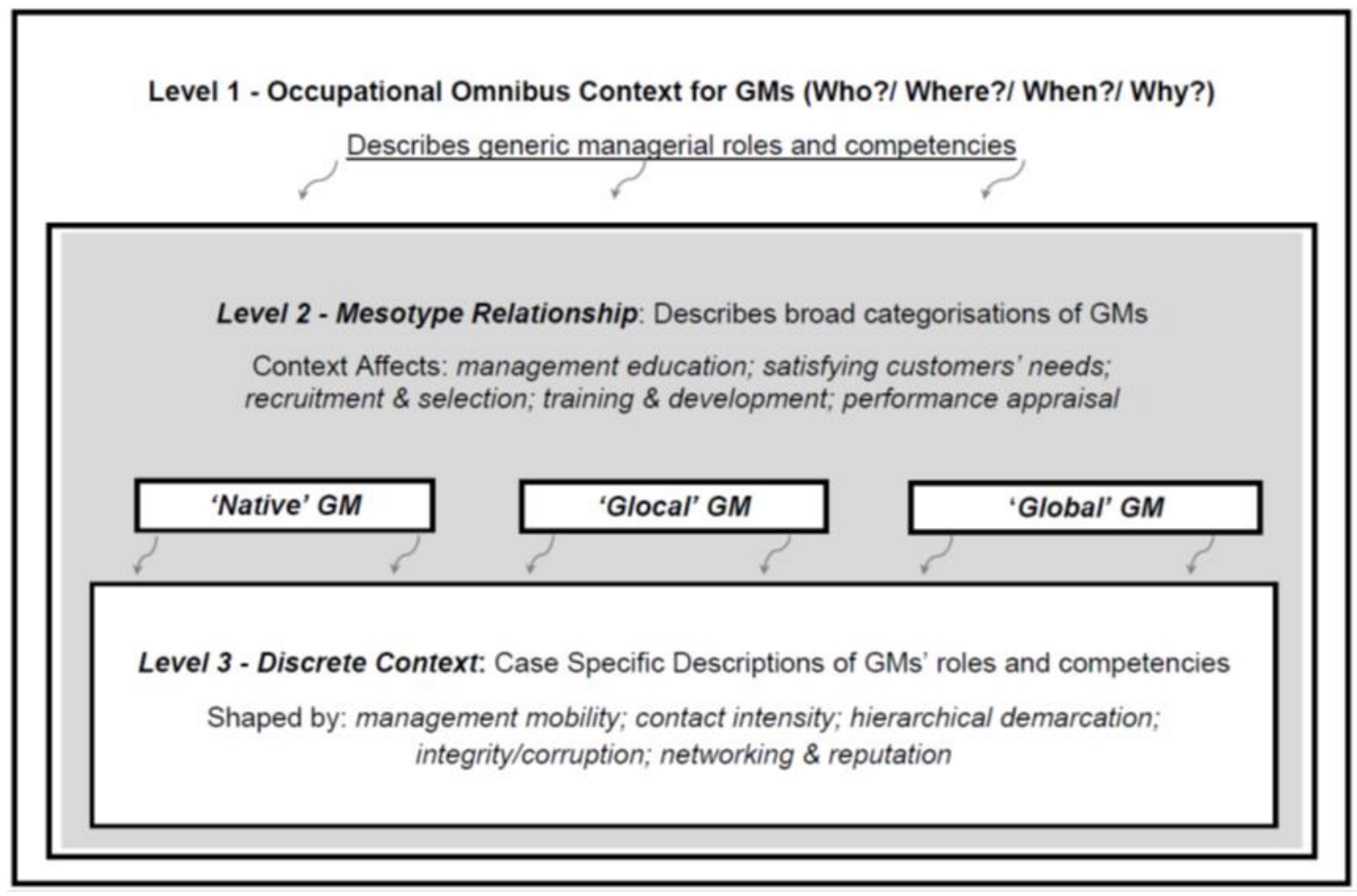

Figure 1 The context of managerial work in luxury hotels

In terms of its practical contribution, these results also have a number of implications for corporate ownership representatives, Greek hotel owners and managers aspiring to be luxury hotel unit GMs in the Greek and international hotel industry. Corporate ownership representatives from MNC hotel chains should revisit their persistence in 'best practice' orientation since the international hospitality research clearly indicates that contextual influences affect managerial work. The failure of expatriate 
managers to understand the importance of national and local context is the wake-up call for the multinational corporations in the new millennia. The dominance of the North American 'one-size fits all' mind set must give space to the more pragmatic 'think global - act local'. The rapidly growing trend in the use of host country $(\mathrm{HCN})$ and third country $(\mathrm{TCN})$ nationals demonstrates the difficulty of the American international hospitality corporations to cope with the local challenges. The creation of truly global managerial 'cadres' who can simultaneously embrace local and 'best' practices, has produced spectacular results in non-American international hospitality corporations (Nickson \& Warhust, 2001) such as the Accor group from France. In addition, the existence of IHRM and SIHRM strategies are the key for the successful development and deployment of the hotel GMs in the company's properties worldwide. The central point in the development of such a management cohort is focused in cultural/contextual awareness and the ability of the expatriate managers to create networks and communicate with people in the host country.

On the other hand, local luxury hotel owners in Greece and to a great extend in the European south (Portugal, Spain, Italy and southern France), need to acknowledge that hotel senior managers act as the key mediators and facilitators of their companies' strategies and they are pivotal in transferring proprietary knowledge, managing resources and driving revenues and reputations of specific hotel units and companies. Hotel senior managers are often seen - especially in family business - as a 'necessary expense'. The lack of formality and absence of formal authority limits within family business can be threatening for the work of the hotel's senior managers. Moreover, the 'family like' work environment consistent with the Greek and southern European cultural context, poses as one of the greater challenges for hotel managers who find themselves trapped in crossfire between family member disputes.

Nevertheless, the adoption of the 'traditional' Swiss/French (European) management model which exemplifies craft and technical skills (Guerrier, 1987) have proven successful for family business and local hotel chains, still dominant in the E.U. lodging industry (Eurostat, 2012). On the other hand, when hotel owners decide to expand regional or nationwide, they necessarily need to turn to managers with 'American' attitude, which emphasizes in generic business and management skills (Bignold, 2006; Jauncey, 2000; Nebel et al., 1995). The challenge here is not addressing hotel managers but the 
hotel owners themselves who must convert the 'small business' mindset, to corporate mentality. The example of successful Greek national hotel managers proves that a hybrid model can exist, where small business thinking meets corporate mentality and the 'family like' work environment for managers has eliminated most negative contextual influences (i.e. favouritism in selection or performance evaluation). The bottom line for family hotel owners is that they need to evolve and escape from the paternalistic management style, which is a major drawback for the work of the senior hotel managers.

Managers aspiring to be luxury hotel unit GMs in the Greek and international hotel industry, must be aware of the unique challenges attached to this job. The multidimensional facet of the hotel manager's job requires young talented and highly qualified candidates who are willing to learn and develop themselves in a continuous process, even when they reach the peak of their career. A very important aspect of managerial work that is not taught in hospitality and business curricula is the understanding of context. The frequent relocations within and/or outside the country of origin, requires from hotel managers to develop instant situational and contextual awareness in order to be able to adapt to new environments. Adaptation is the prerequisite for hotel managers to be efficient and productive. Globalisation demands hotel managers to behave and work in a similar manner and at the same time, to be able to understand the local work environment. There is no golden rule in the adoption of specific roles and competences, since each manager decides personally what works better in his/her case. Another unseen and often ignored quality of hotel managers is the ability to infiltrate and participate in 'professional' networks that provide valuable information or even assist in their career progression. Overall, aspiring hotel GMs are expected to perform in a volatile working environment and very often exceed the limits of job descriptions. Management mobility is expected throughout the individual's career progression; the 'traditional' career paths (through the Food \& Beverage and Front Office departments) are not adequate for the new cohort of aspirant hotel GMs who also need to acquire generic business skills.

As a concluding thought, it can be argued that the results of this research can contribute in the redesign and reshape of hospitality management curricula, since the future managers must be able to 
cope with a vast array of needs and demands. It is hoped that the findings of this study will establish a good starting point for future research.

\section{References}

Adler, H., \& Rigg, J. (2012). Expatriate Hotel General Managers in Jamaica: Perceptions of Human Resource, Organizational, and Operational Challenges. J Hotel Bus Manage, 1(104), 2169-0286.

Agut, S., Grau, R., and Peiro, J.M. (2003). Competency needs among managers from Spanish hotels and restaurants and their training demands. Hospitality Management, 22, 281-295.

Biddle, B. J. (1979). Role theory: Expectations, identities, and behaviour. New York: Academic Press.

Bignold, D. (2006). Schooled and Tooled, Caterer and Hotelkeeper. 10-16th August, 23-25.

Blayney, C. (2009). Management Competencies: Are they related to Hotel Performance? International Journal of Management and Marketing Research, 2, (1), 59-71.

Boyacigiller, N.A. and Alder, N.J. (1991). The parochial dinosaur: Organisational science in a global context. Academy of Management Review, 16, (2), 262-290.

Burrell, G. and Morgan, G. (1979). Sociological Paradigms and Organisational Analysis. Aldershot: Gower.

Cappelli, P., and Sherer, P. D. (1991). The missing role of context in OB: The need for a meso-level approach. Research in organizational behavior, 13, 55-110.

Carlson, S. (1951). Executive Behaviour. Stockholm: Strömbergs.

Christou, E. (1999). Hospitality management education in Greece: An exploratory study. Tourism Management, 20, 683-691.

Christou, E. and Eaton, J. (2000). Management Competencies for Graduate Trainees. Annals of Tourism Research, 24(4), 1058-106.

Cortada, J. (2009). Power and use of context in business management, Journal of Knowledge Management. 13 (3), pp.13-27.

D'Annunzio-Green, N. (1997). Developing international managers in the hospitality industry. International Journal of Contemporary Hospitality Management, 9(5/6), 199-208.

Decrop, A. (1999). Triangulation in Qualitative Tourism Research. Tourism Management, 20, 157-161.

Denzin, N.K. and Lincoln, Y.S. (2003). The Landscape of Qualitative Research. Thousand Oaks: Sage.

Dierdorff, E., Rubin, R. and Morgeson, F. (2009). The Milieu of Managerial Work: An Integrative Framework Linking Work Context to Role Requirements. Journal of Applied Psychology, 94(4), 972-988.

Dierdorff, E.C. and Morgeson, F.P. (2007). Consensus in work role requirements: The influence of discrete occupational context on role expectations. Journal of Applied Psychology, 92(5), 1228-1241.

Dierdorff, E.C. and Rubin, R. S. (2007). Carelessness and discriminability of work role requirement judgments: Influences of role ambiguity and cognitive complexity. Personnel Psychology, 60, 597-625.

Feng, F. and Pearson, T.E. (1999). Hotel Expatriates in China: selection criteria, important skills and knowledge, repatriation concerns, and causes of failure. International Journal of Hospitality Management, 18(2), 309321

Field, H.M. (1995). Financial management implications of hotel management contract agreements: a UK perspective. In Harris, P.J. (Ed.) Accounting and Finance in the International Hospitality Industry, (pp.261-277) Oxford: Butterworth-Heinemann.

Gilatis, N. and Guerrier, Y. (1994). Managing international career moves in international hotel companies. In Cooper, C.P. and Lockwood, A. (Eds.) Progress in Tourism, Recreation and Hospitality Management, 5, 229-241.

Gilbert, D. and Guerrier, Y. (1997). UK hospitality managers: past and present, Service Industries Journal. 17(1), 115-132.

Giousmpasoglou, C. (2012). The context of managerial work in luxury hotels in Greece: A roles, competencies and culture approach. Saarbrücken: LAP.

Graen, G.B. (1976). Role making processes within complex organizations. In Dunnette, M.D. (Ed.) Handbook of industrial and organizational Psychology, (pp.1201-1245). Chicago: Rand McNally.

Grönroos, C. (2001). The perceived service quality concept - a mistake? Managing Service Quality, 11(3), 150152.

Guba, E.G., and Lincoln, Y.S. (1994). Competing paradigms in qualitative research. In Denzin, N.K. and Lincoln, Y.S. (Eds) Handbook of qualitative research (pp.105-117). Thousand Oaks: Sage.

Guerrier, Y. and Deery, M. (1998). Research in hospitality human resource management and organizational behaviour. International Journal of Hospitality Management, 17, 145-160. 
Guerrier, Y. (1987). Hotel managers' careers their impact on hotels in Britain, International Journal of Hospitality Management, 6(3), 121-130.

Guilding, C. (2006). Investment appraisal issues arising in hotels governed by a management contract. In Harris, P. and Mongiello, M. (Eds) Accounting and Financial Management: Developments in the International Hospitality Industry, (pp.400-422), Oxford: Butterworth Heinemann.

Hales, C. and Tamangani, Z. (1996). An investigation of the relationship between organisational structure, managerial role expectations and managers' work activities. Journal of Management Studies, 33, 731-756.

Hammer, T.H., and Turk, J.M. (1987). Organizational determinants of leader behavior and authority. Journal of Applied Psychology, 72, 674-682.

Hannaway, J. (1989). Managers managing: the workings of an administrative system. New York: Oxford University Press.

Harris, M. (2008). Summary and Conclusions. In Harris, M. (Ed.) Handbook of research in international human resources, (pp.229-243). London: Lawrence Erlbaum Associates.

Hattrup, K., and Jackson, S. E. (1996). Learning about individual differences by taking situations seriously. In Murphy, K.R. (Ed.) Individual differences and behavior in organizations (pp. 507-547). San Francisco: Jossey-Bass,.

House, R., Rousseau, D. M., and Thomas-Hunt, M. (1995). The meso-paradigm: A framework for the integration of micro and macro organizational behaviour. In Staw, B.M. and Cummings, L.L. (Eds.) Research in organizational behavior, Greenwich: JAI Press, 17, 71-114.

House, R.J., Hanges, P.J., Javidan, M., Dorfman, P. and Gupta, V. (2004). Leadership, Culture and Organisations: The Globe Study of 62 Societies, Thousand Oaks: Sage.

Ilgen, D.R. and Hollenbeck, J.R. (1991). The structure of work: Job design and roles. In Dunnette, M.D. and Hough, L.M. (Eds.) Handbook of industrial and organizational psychology, (pp.165-207). Palo Alto, CA: Consulting Psychologists Press.

Jauhari, V. (2006). Competencies for a career in the hospitality industry: an Indian perspective. International Journal of Contemporary Hospitality Management, 18(2), 123-134.

Jauncey, S.A. (2000). The Job of the Hotel General Manager: An Ethnographic Study of Unit Managers from one Occupational Community. Unpublished PhD thesis: Oxford Brookes University.

Javidan, M., Stahl, G.S., Brodbeck, J. and Wilderom, C.P.M. (2005). Cross-border transfer of knowledge: Cultural lessons from Project Globe. Academy of Management Executive, 19(2), 59-76.

Johns, G. (2006). The essential impact of context on organizational behaviour. Academy of Management Review, 31(2), 386-408.

Kahn, R. L., Wolfe, D.M., Quinn, R.P., Snoek, J.D. and Rosenthal, R.A. (1964). Organizational stress: Studies in role conflict and ambiguity. New York: Wiley.

Katz, D. and Kahn, R. (1978). The social psychology of organizations. $2^{\text {nd }}$ Edition, New York: Wiley

Kim, S.M. (1994). Tourist hotel general managers in Korea: a profile. International Journal of Hospitality Management, 13(1), 7-17.

Kotter, J. (1982). What effective general managers really do. Harvard Business Review, 60(6), 156-167.

Kriegl, U. (2000). International hospitality management. Cornell Hotel and Restaurant Administration Quarterly, 41(2), 64-71.

Ladkin, A. and Juwaheer, D.T. (2000). The career paths of hotel general managers in Mauritius. International Journal of Contemporary Hospitality Management, 12(2), 119-25.

Litteljohn, D. (2003). Hotels. In Brotherton, B. (Ed.) The International Hospitality Industry: Structure, Characteristics and Issues (pp.5-29). Oxford: Butterworth-Heinemann.

Luthans, F., Rosenkrantz, S. and Hennessey, H. (1985). What do successful managers Really Do? An Observation Study of Managerial Activities. The Journal of Applied Behavioural Science, 21(3), 255-270.

Miao, L., Adler, H., \& Xu, X. (2011). A stakeholder approach to expatriate management: Perceptions of hotel expatriate managers in China. International Journal of Hospitality Management, 30(3), 530-541.

Mintzberg, H. (1973). The nature of Managerial Work. New York: Harper \& Row.

Mintzberg, H. (1994). Rounding out the Manager's Job. Sloan Management Review, Fall, 11-26.

Morgeson, F.P. and Campion, M.A. (1997). Social and cognitive sources of potential inaccuracy in job analysis. Journal of Applied Psychology, 82, 627-655.

Mowday, R.T. and Sutton, R.I. (1993). Organizational behavior: Linking individuals and groups to organizational contexts. Annual Review of Psychology, 44, 195-229.

Nebel, E. C. and Ghei, A. (1993). A conceptual framework of the hotel general manager's job. Hospitality Research Journal, 16(3), 27-37.

Nebel, E.C., Lee, J. and Vidakovic, B. (1995). Hotel general manager career paths in the United States. International Journal of Hospitality Management, 14(3/4), 245-260.

Nickson, D. (1998). A Review of Hotel Internationalisation with a Particular Focus on the Key Role Played by American Organisations. Progress in Tourism and Hospitality Research, 4, 53-66. 
Osborn, R. N., and Hunt, J. G. (1975). An adaptive-reactive theory of leadership: The role of macro variables in leadership research. In Hunt J.G. and Larson L.L. (Eds.), Leadership frontiers (pp.27-44). Kent: Kent State University Press.

Parasuraman, A., Berry, L. and Zeithaml,V. (1985). A Conceptual Model of Service Quality and Its Implications for Future Research. Journal of Marketing, 49(4), 41-50.

Perry, C. (1998). A structured approach to presenting theses. Australian Marketing Journal, 6(1), 63-86.

Price, S. (1993). Strategic groups and foreign investment in the International Hotel Industry. MBA dissertation: University of Bradford.

Sanchez, J.I. and Levine, E.L. (2001). The analysis of work in the 20th and 21st centuries. In N. Anderson, D.S. Ones, H.K. Sinangil, and Viswesvaran, C. (Eds.) International handbook of work and organizational Psychology, (pp.71-89). Thousand Oaks: Sage.

Sayles, L. R. (1964). Managerial Behaviour. New York: McGraw-Hill.

Schein, E. (1992). Organizational culture and leadership. $2^{\text {nd }}$ Edition, San Francisco: Jossey-Bass.

Schneider, B. (1983). Interactional psychology and organizational behaviour. In B. M. Staw and L. L. Cummings (Eds.) Research in organizational behaviour. Greenwich: JAI Press, 5, 1-31.

Segal-Horn, S. (1994). Are Service Industries going Global? In Armistead, C. (Ed.) The Future of Services Management, The Cranfield Management Research Series (pp.41-63). London: Kogan Page.

Shay, J. and Tracey, J.B. (1997). Expatriate Managers: Reasons for failure and implications for training. Cornell Hotel and Restaurant Administration Quarterly, February, 38(1), 30-35.

Silverman, D. (2000). Doing Qualitative Research: A Practical Handbook. London: Sage.

Stake, R.E. (1995). The art of case study research: perspectives and practice. London: Sage.

Stewart, R. (1982). A model for understanding managerial jobs and behaviour. Academy of Management Review, 7(1), 7-13.

Strong, M. H., Jeanneret, P. R., McPhail, S. M., Blakey, B. R., and D’Egidio, E. L. (1999). Work context: Taxonomy and measurement of the work Environment. In Peterson, N.G., Mumford, M.D., Borman, W.C., Jeanneret, P.R. and Fleishman, E.A. (Eds.) An ccupational information system for the 21st century: The development of $O \_N E T$ (pp.127-146). Washington: American Psychological Association.

Thomas, D.C. (2008). Cross-Cultural Management: Essential Concepts. $2^{\text {nd }}$ Edition, London: Sage.

Thompson, P., Nickson, D., Wallace, T. and Jones, C. (1998). Internationalisation and Integration: A Comparison of Manufacturing and Service Firms. Competition and Change, 3, 387-415.

Thornton, R. and Nardi, R.M. (1975). The dynamics of role acquisition. American Journal of Sociology, 80, $870-885$.

Von Glinow, M.A., Drost, E. and Teagarden, M. (2005). Counterintuitive Findings in International HRM Research and Practice: When Is a Best Practice Not Best for Practice? In Losey, M., Meisinger, S. and Urlich, D. (Eds) The future of Human Resource Management (pp. 392-399). Alexandria (Virginia): Society for Human Resource Management,.

Watson, T.J. (2001). In search of management. London: Routledge

Weick, K. E. (1979). The social psychology of organizing. $2^{\text {nd }}$ Edition, Reading: Addison-Wesley.

Yin, R.K. (2003). Case Study Research - Design and Methods. $3^{\text {rd }}$ Edition, London: Sage. 


\section{Appendix 1: Semi-Structure Interviews}

Qualitative analysis of managerial roles \& competencies, and the influence of the context Question 1:

- Please describe briefly your professional background

\section{Question 2:}

- What was your main motive for choosing this profession?

\section{Question 3:}

- In your opinion which part of your job do you consider as most important?

\section{Question 4:}

- Please describe a) the Recruitment and b) Selection process for upper management employees (GM \& Dept. Mgrs) in your hotel.

\section{Question 5:}

- Please describe the Training \& Development process for managerial staff in your hotel. How do you contribute in this process?

\section{Question 6:}

- Please describe your formal and informal roles in day-to-day operations.

\section{Question 7:}

- What competencies do you consider important to deal with the following groups:

- Superiors / Ownership

- Employees \& workers
- Supervisors

- Customers
- Public Sector

- Suppliers

\section{Question 8:}

- What you perceive as the ideal competencies mix for upper managerial staff in Greek $4 \& 5^{*}$ hotels?

\section{Question 9:}

- Please describe the performance evaluation system in your hotel.

\section{Question 10:}

- What is the role of networking and communication in your work? What is the role of a GM's reputation in the market?

\section{Question 11:}

- What are the similarities and differences between family owned, Greek chain and international chain $4 \& 5^{*}$ hotels operating in Greece?

\section{Question 12:}

- Do you think that the Greek context (culture, national identity, values, family, distinctive personal characteristics) influences the GMs' professional profile?

\section{Question 13:}

- What are the differences and similarities with what is called "international (western) hotel management" considering the current situation in Greece?

\section{Question 14:}

- Comments - discussion 
Appendix 2: Research protocol

\begin{tabular}{|c|c|c|}
\hline Activity & \multicolumn{2}{|l|}{ Description } \\
\hline $\begin{array}{l}\text { Research } \\
\text { aims guiding } \\
\text { the research } \\
\text { questions }\end{array}$ & \multicolumn{2}{|c|}{$\begin{array}{l}\text { To explore the interplay of context with managerial work in the } \\
\text { Greek luxury hotel sector. }\end{array}$} \\
\hline $\begin{array}{l}\text { Research } \\
\text { method / } \\
\text { design }\end{array}$ & $\begin{array}{l}\text { Country qualitative research in } 16 \text { luxury hotels } \\
\text { with } 32 \text { participant managers, in } 4 \text { different } \\
\text { locations (Athens, Thessaloniki, Rhodes, Crete) }\end{array}$ & $\begin{array}{l}\text { Field Work } \\
\text { Duration: } \\
\text { 04/2011- } \\
10 / 2011 \\
\end{array}$ \\
\hline $\begin{array}{l}\text { Participant } \\
\text { selection } \\
\text { process }\end{array}$ & \multicolumn{2}{|c|}{$\begin{array}{l}\text { Prerequisite for participant interviewees is to belong in the target } \\
\text { group: hotel GMs and senior managers (Operation managers; Food } \\
\text { \& Beverage managers; Front Office Managers; HR - Personnel } \\
\text { Managers). }\end{array}$} \\
\hline $\begin{array}{l}\text { Case } \\
\text { selection } \\
\text { process }\end{array}$ & \multicolumn{2}{|c|}{$\begin{array}{l}\text { Basic prerequisite for the participant hotels is to have } 4^{*} \text { or } 5^{*} \\
\text { official rating in Athens, Thessaloniki, Crete and Rhodes - } \\
\text { representing city and resort hotels respectively. All hotels must } \\
\text { have more than } 150 \text { rooms / also provide TV and air-conditioning in } \\
\text { rooms / bar-restaurant and parking / swimming pool (resorts only). }\end{array}$} \\
\hline Case access & \multicolumn{2}{|c|}{$\begin{array}{l}>\text { Identify hotels fulfilling the criteria in the research protocol. } \\
\text { Negotiate full access to the case through written } \\
\text { and/or verbal permission. } \\
\text { Meet to establish researcher/participant rapport } \\
\text { prior to the interviews. }\end{array}$} \\
\hline $\begin{array}{l}\text { Research } \\
\text { instruments }\end{array}$ & \multicolumn{2}{|c|}{$\begin{array}{l}\text { In-depth semi-structured interviews, non-participant observation } \\
\text { (including company documents) }\end{array}$} \\
\hline $\begin{array}{l}\text { Boundary } \\
\text { device }\end{array}$ & \multicolumn{2}{|c|}{$\begin{array}{l}\text { Luxury hotel senior managers' roles within a specific cultural } \\
\text { context (Greece) }\end{array}$} \\
\hline $\begin{array}{l}\text { Research } \\
\text { techniques }\end{array}$ & \multicolumn{2}{|c|}{$\begin{array}{l}\text { On-site semi-structured in-depth interviews for GM's and Dept. } \\
\text { Managers; informal conversations before and after the visit in } \\
\text { hotels. Maintenance of reflective field notes. Company document } \\
\text { collection. }\end{array}$} \\
\hline $\begin{array}{c}\text { Data } \\
\text { management }\end{array}$ & \multicolumn{2}{|c|}{$\begin{array}{l}\text { Employ tests for quality research (construct and external validity, } \\
\text { reliability) and use data and method triangulation. }\end{array}$} \\
\hline
\end{tabular}

(Source: adapted from Yin, 1994) 